\title{
Educational and Cultural Aspects of Digitalization of Economy
}

\author{
Saiko D.S.* \\ Department of Higher Mathematics and Information \\ Technology \\ Voronezh State University of Engineering Technologies \\ Voronezh, Russia \\ e-mail: dmsajko@mail.ru
}

\author{
Kovaleva E.N. \\ Department of Higher Mathematics and Information \\ Technology \\ Voronezh State University of Engineering Technologies \\ Voronezh, Russia \\ e-mail: kovaleva.lena@gmail.com
}

Lemeshkin A.V.

Department of Higher Mathematics and Information Technology

Voronezh State University of Engineering Technologies

Voronezh, Russia

e-mail: sansan55@mail.ru

\begin{abstract}
The modern educational system has passed the active phase of computerization and informatisation. Humanity has entered to the era of digitalization. The information component in politics and economics is in the process of strengthening in the modern world. Digital economy is not only the foundation for creating new business models, the nature of doing business, its manageability and flexibility, qualitative changes in business models, but also it affects the fundamental foundations of civilization. Due to the trend towards digitalization of the economy, the requirements for the level of education at universities are increasing significantly. The article discusses the construction of individual educational trajectories of students, the development of integration projects "school university - enterprise", as a result of which we will get a modern system of professional self-determination of students and the development of potential teachers for the "digital university". The article explores the changes that digitalization of the economy makes in the cultural and educational sphere of human life. The authors concluded that Russia has all the necessary prerequisites for the further implementation of digital acceleration and the potential for digitalization of the economy. New technologies will have a great impact on the development of state and business administration, the growth of the quality of life, the emergence of new forms of people's socialization, their skills and communication culture. Russia has the necessary scientific and intellectual base. There are many original technological solutions for making an effective infrastructure of digital economy.
\end{abstract}

Keywords - digitalization, education, companies, rating, digital economy, information and communication technologies,

\author{
Medvedkova I.E. \\ Department of Higher Mathematics and Information \\ Technology \\ Voronezh State University of Engineering Technologies \\ Voronezh, Russia \\ e-mail: fi28@mail.ru \\ Chernyaeva S.N. \\ Department of Higher Mathematics and Information \\ Technology \\ Voronezh State University of Engineering Technologies \\ Voronezh, Russia \\ e-mail: chernsv1978@gmail.com
}

\author{
Matytsina I.A. \\ Faculty of Secondary Vocational Education \\ Voronezh State University of Engineering Technologies \\ Voronezh, Russia \\ e-mail: irina210390@mail.ru
}

transformation effects, digital economy indicators, innovations, economic growth, global information space

\section{INTRODUCTION}

The high speed of the digitalization process of the economy leads to global changes in social processes and people's lives. Despite the many interpretations of the term "digital technology", the content of the concept remains blurred. Most often, a digital economy refers to a set of economic and social activities that are provided by information and communication technologies, such as the Internet, mobile and IoT (Internet of Things) networks, including communications, financial transactions, education, entertainment and other types of business based on the use of computers, smartphones and other devices.

The change of cultural values is happening right before our eyes. The younger generation lives in the digital format. This generation perceives the format of traditional culture with the established system of values through the prism of numbers and emerging consequences: such as clip culture, screen culture, the culture of computer games, etc. The main phenomenon that defines a single modern digital culture includes a personal computer and the whole variety of digital devices. The fact is that there is currently a boom in applications written for standard personal computer operating systems that allow performing routine tasks related to technical computing and programming much faster. However, the number of applications written for Android and IOS in recent years exceeds all imagination. Just look at existing applications in 
Apple Store. Among them, now there are a huge number of various solvers. They allow performing quite complex technical calculations in certain areas of mathematics, physics, chemistry and information technology. There is already quite obvious competition in various sections between these software applications.

The urgent problem is the formation of a special type of culture in the digital age. The cultural significance of digital media, regardless of their strengths or weaknesses, is obvious. "With their spread, changes occur that affect the daily lives of people, established cultural hierarchies, the ways in which people interact with each other and the world around them. The system of the formation of cultural experience as a whole and all the basic spheres of culture are changing" [1]. Each student brings digitalization to the university in his gadget (smartphone, tablet, etc.). Extreme ease of use and visualization, maximum data transfer rate - these are the main components of digitization

Mastering of economic knowledge at the university, as we know, has its own specifics. It should be noted that students' awareness of the important role of applied mathematics and computer science in modern digital society and economics leads to the actualization of the study of mathematics at the university and school. Recently, a question has been sharply raised related to the problems of economic and mathematical education of students. Applicants applying to engineering degree from the technical college have to be prepared to the further development of economic disciplines and application of school knowledge obtained in practice [2].

On December 24, 2013, the Concept of the development of mathematical education was approved, which notes [3] that "without a high level of mathematical education, the task of creating an innovative economy is impossible". The goal of the developed Concept is: "Improving the quality of General and vocational education, the level of math literacy, efficiency in the use of mathematical methods and tools in a wide range of professional activities; access to world level in the field of information and communications technology (ICT), growth of the share of the highest achievements in mathematics and computer science that belong to the national scientists" [4].

On July 28, 2017, the "Digital Economy" program [5] was approved, which states: "The educational system is faced with the task of learning. This requires a restructuring of the education system in universities and the thinking of teachers themselves". It is important to continuously grow the number of students choosing IT-training areas.

In addition to the new requirements for higher education in the training of specialists adequate to the requirements of the modern labor market, certain changes must occur with primary and secondary education. According to the work [6] only 17 percent of graduates of $9^{\text {th }}$ and $11^{\text {th }}$ classes choose IT profession. Growth indicators can be achieved through courses, career guidance, and attention to schools and universities to the problem that students do not always choose their future profession consciously and in accordance with the state of things in the modern world.
In this regard, it is necessary to analyze the current digitalization situation in all spheres of human life, consider the characteristics and features of the transition to a "digital culture" and identify the main educational and cultural aspects of the formation of the digital economy.

\section{MethodOLOGY}

To analyze the impact of digitalization on modern life, the ratings of the 7 largest global companies and the contribution of the digital economy to Russia's gross domestic product (GDP) compared to other countries were reviewed.

The aim of the study is to assess the level of readiness of universities for the use of digital technologies and the introduction of new information technologies in the educational process at the Voronezh State University of Engineering Technologies. The cultural aspects of digitalization of the economy are also considered.

To achieve this goal, the following tasks are set:

1. To analyze the activity of introducing the main digital information and communication technologies in the economy.

2. To analyze how big data, neurotechnologies and artificial intelligence, distributed registry systems (blockchain), quantum technologies, new manufacturing technologies, the industrial Internet, robotics and sensor components, wireless technologies, virtual and augmented reality technologies are introduced into the educational process of the university.

2. To create a rating of world companies showing the size of the use of digital technology.

3. To analyze the use of digital technology in foreign practice.

4. To consider the cultural aspects of digitalization of the economy.

5. To recommend modern means of informatisation for implementation in the educational process.

Promising digital technologies in the educational and cultural fields are studied using methods such as the analysis of statistical data, the generalization of estimates of existing reviews, and the identification and elimination of gaps in the proposed digitalization conditions.

The study uses statistics that can be used to assess the digitalization of the Russian economy as a whole, as well as educational and cultural prerequisites for creating a "digital university" in particular.

The important problem is to investigate influence of the process of digitalization of economy on new forms of socialization of people and their communication. This is important, because in the conditions of the formation of a modern digital economy, it is necessary to pose the problem of forming the economic competence of students of our university, not only teachers of schools and universities, but also employers associated with production and familiar with the situation in the "real economy". 
The object of the study is digital technology, considered as a priority in the economic development of Russia. According to the work [7], the share of the municipalities of the Voronezh region that have introduced the target model of the digital educational environment in educational institutions $11 \%$ (21143 people).

It was emphasized at the University of National Technology Initiative (NTI) "20.35" (competency center "Personnel for the Digital Economy") that by 2024, model elements of a digital university should be implemented in all Russian universities. Each student must have access to the requested educational content, effective learning technologies and digital services support. "This is the only possible solution if we want to increase admission numbers and ensure equal opportunities for training and development of all higher educational institutions of the country", - noted Director of training for the digital economy at the University of NTI "20.35" Oleg Podolsky [8].

It is of fundamental importance for us that the Digital University works with the entire target audience, all interested parties in the educational process: with students, researchers, teachers, and administration. It is fundamentally important for Russia in the ever-changing conditions of demand in the labor market to have the ability to build a personal development path.

By October of this year, a core competency model for the digital economy will be developed and presented. This should be in the interests of business and the labor market. It is expected that the new tool will meet state standards in the field of education.

\section{RESULTS}

It is analyzed at the University of NTI " 20.35 " the skills and knowledge of which are in demand in 50 leading companies, and identified 211 competencies, divided into nine blocks. The most popular block for employers is "thinking".

International studies show that a lack of highly qualified specialists is encountered in most countries. According to Korn Ferry, by 2030 the global economy will have a deficit of 85.2 million people. Most (74 \%) of the leaders of the largest organizations in the world believe that in the future, technologies will make a greater contribution to creating business value, the human factor [9]. At the same time, highly qualified personnel will be especially valuable.

We believe that, as a generalization and systematization of knowledge and methods of activity, students can be offered to perform research work, such as essay on a selected topic, creating Web sites. Voronezh State University of Engineering Technologies holds "Open Doors Days", both university-wide and individual faculties, in the framework of which excursions are held, including the demonstration of the latest achievements of science and technology, exhibitions, master classes, open lessons in professions, quest- tournaments, olympiads in economics, in which children from sponsored schools are happy to participate.

The author of the article "A New Era. Why should the school participate in the development of the digital economy"
Olesya Gor'kovaya believes [10]: "It is important to understand that in modern conditions, not just a university entrant should leave the walls of a school, but a citizen adapted to life in the digital world. There is a simple dependency: the younger the user, the more successfully we can implement digital technology. Today's students use devices more often and better than university graduates, not to mention an elder generation. But even this does not mean that the owner of the smartphone knows how to live "in digital terms". What skills should modern students master and what is the role of the school in the process of educating tomorrow's innovators?"

The relevance of this problem is understood all over the world: the European Commission, together with UNESCO, has launched a program that includes Russia. After its pilot launch at the end of last year, the European Commission invited interested schools to check how successfully they use technological tools in the educational process. About one million students and teachers are expected to use the service by the end of 2019 [11].

TABLE I. THE RATING OF THE LARGEST COMPANIES IN THE WORLD, 2017

\begin{tabular}{|c|c|c|}
\hline Company & Field of activity (core) & $\begin{array}{c}\text { Market capitalization } \\
\text { in 2017, billion US } \\
\text { dollars }\end{array}$ \\
\hline Apple & $\begin{array}{c}\text { Electronics and Information } \\
\text { Technology }\end{array}$ & 618 \\
\hline $\begin{array}{c}\text { Alphabet } \\
\text { (Google) }\end{array}$ & $\begin{array}{c}\text { Internet services, applications, } \\
\text { video hosting }\end{array}$ & 532 \\
\hline Microsoft & Software development & 483 \\
\hline Amazon & $\begin{array}{c}\text { Retail company: sale and delivery } \\
\text { of various goods over the Internet }\end{array}$ & 356 \\
\hline Facebook & Internet & 332 \\
\hline $\begin{array}{c}\text { General } \\
\text { Electric }\end{array}$ & $\begin{array}{c}\text { Production of electrical, energy, } \\
\text { medical equipment, household } \\
\text { appliances; transport engineering }\end{array}$ & 280 \\
\hline
\end{tabular}

From TABLE I (data taken from [12]) it is seen that in the modern economy, companies that use digital technologies are becoming growth points that provide the economy with a digital resource. "The contribution of the digital economy to Russia's gross domestic product (GDP) today is $2.8 \%$ - about a fifth of GDP is formed by Internet-dependent markets. By themselves, these figures are already impressive, but they will grow significantly in the next decade. This means that the shortage of IT-specialists, existing now, will only grow.

According to experts, over the past ten years, the Russian economy should be replenished with 2 million IT-specialists. To get closer to this figure, Russian universities should increase the number of graduates of "digital" specialties to at least 100,000 people a year $(40,000$ more than current indicators). However, digital economy is not only the programmers who come up with the new Uber, but also the comprehensive penetration of technologies into those areas whose digitalization is difficult to imagine [13]. About $40 \%$ of the country's population should have digital skills, regardless of the chosen specialty. If we exaggerate, then even the farmer must understand the basics of IT in order to be able to deal with the technological tools necessary for milking and working with agricultural machinery [14]. 
Fundamental knowledge is what the school should teach. Along with the last call, modern society should not just get a university entrant, but no matter how loud it sounds, a citizen who possesses all the necessary knowledge for life in this society. The school, in addition to the Russian language, mathematics and chemistry, must also teach social and financial literacy. Since our world unconditionally embarked on the rails of digitalization we should prepare a competent user. Otherwise, we can get a generation of those who are not able to function in society. And not only can this lead to largescale social consequences, but also jeopardize the transition to the digital economy.

TABLE II. THE CONTRIBUTION OF THE DIGITAL ECONOMY TO RUSSIA'S GDP COMPARED TO OTHER COUNTRIES, 2017

\begin{tabular}{|l|c|l|l|l|l|l|}
\hline $\begin{array}{c}\text { The } \\
\text { country }\end{array}$ & $\begin{array}{c}\text { Share } \\
\text { in } \\
\text { GDP, } \\
\mathbf{\%}\end{array}$ & $\begin{array}{c}\text { Costs } \\
\text { households } \\
\text { in digital } \\
\text { sphere, } \%\end{array}$ & $\begin{array}{c}\text { Investments } \\
\text { companies in } \\
\text { digitalizetion, } \\
\mathbf{\%}\end{array}$ & $\begin{array}{c}\text { State } \\
\text { expenses for } \\
\text { digitalizetion, } \\
\mathbf{\%}\end{array}$ & $\begin{array}{c}\text { ICT } \\
\text { export, } \\
\text { \% }\end{array}$ & $\begin{array}{c}\text { ICT } \\
\text { import, } \\
\text { \% }\end{array}$ \\
\hline USA & 10,9 & 5,3 & 5,0 & 1,3 & 1,4 & $-2,1$ \\
\hline China & 10,0 & 4,8 & 1,8 & 0,4 & 5,8 & $-2,7$ \\
\hline $\begin{array}{l}\text { EU } \\
\text { count- } \\
\text { ries }\end{array}$ & 8,2 & 3,7 & 3,9 & 1,0 & 2,5 & $-2,9$ \\
\hline Brazil & 6,2 & 2,7 & 3,6 & 0,8 & 0,1 & $-1,0$ \\
\hline India & 5,5 & 2,2 & 2,0 & 0,5 & 2,9 & $-2,1$ \\
\hline Russia & 3,9 & 2,6 & 2,2 & 0,5 & 0,5 & $-1,8$ \\
\hline
\end{tabular}

TABLE II (data taken from Report "Digital Economy: Global Trends and Practice of Russian Business, 2018") shows the annual increase in the share of the digital economy in GDP in the world by almost $18 \%$, and in developed countries by $7 \%$. This is recognition of the importance of the role of the digital economy in the world.

The most dynamic and significant segments in the digital economy are telecommunications and activities related to the use of computer devices and information technology, which includes software development, consulting, information processing, creation and use of databases and information resources, including the Internet, and maintenance of computer equipment. The response to such changes of an external and internal nature causes a growing demand for the development of science and technology. A radical transformation of markets is taking place in connection with a change in the basic base of technical equipment.

The educational portal of the Voronezh region provides the following information: "The proportion of students enrolled in general education programs, additional education for children and secondary vocational education (for whom a digital educational profile and an individual training plan using the federal information and service platform of the digital educational environment are formed) to the total number of students in these programs is $10 \% / 40.600$ ". In addition, the regional project "Digital School of the Voronezh Region" is being implemented. It is an infrastructure project of the Department of Education, Science and Youth Policy of the Voronezh Region and PAO Rostelecom.

Pupils often have a deceptive impression of their future professional areas of work and chosen specialties, which in the end do not coincide with reality, which harms correct professional self-determination [15]. Therefore, in the framework of career guidance work, in collaboration with Voronezh State University of Engineering Technologies, we try to show the full range of knowledge applications acquired at school, as applied to the future digital economy [16].

At scientific conferences held at the University of Engineering Technology, pupils show real projects related to mathematical modeling of technological processes with numerical implementation on a computer and complete calculation of economic efficiency of production [17]. It also increases the psychological responsibility of students. They work with real databases; receive additional mathematical and economic training. As a result, at the output we get not just a "qualified user of IT technologies", but a graduate aimed at choosing a profession that he likes. This is a huge motivating factor for passing the exam in all selected subjects.

The development of individual educational trajectories, the logic of the recommendations, the formation of the "space samples", and the development of integration projects "school - university - enterprise" as the result will be a modern system of professional self-determination of students and the development of human resources.

\section{CONCLUSION}

Russia has all the necessary prerequisites for the further implementation of the digital potential and it accelerates the pace of digitalization. New technologies will affect the development of business and public administration, the growth of the quality of life, the emergence of new forms of socialization of people and their communications. In general, digitalization will create a synergistic effect and will lead to the overall growth of the Russian economy. At the moment, one of the main obstacles to the development of the digital economy is the lack of coordinated action on the part of the state, business and the scientific community.

TABLE III. THE FINANCING OF THE DIGITAL ECONOMY OF THE RUSSIAN FEDERATION PROGRAM, BILLION RUBLES

\begin{tabular}{|l|l|l|}
\hline \multirow{2}{*}{$\begin{array}{c}\text { Directions of the } \\
\text { "Digital Economy } \\
\text { Program Russian } \\
\text { Federation" }\end{array}$} & \multicolumn{2}{|c|}{$\begin{array}{c}\text { Sources of financing for the period from 2018 } \\
\text { to 2020 }\end{array}$} \\
\cline { 2 - 3 } & \multicolumn{1}{|c|}{ from the budget } & extrabudgetary funds \\
\hline $\begin{array}{l}\text { Information } \\
\text { infrastructure }\end{array}$ & 100 & 336 \\
\hline Information Security & 22.3 & 11.7 \\
\hline $\begin{array}{l}\text { Formation of research } \\
\text { competencies and } \\
\text { technological } \\
\text { groundwork }\end{array}$ & 48 & 2 \\
\hline Normative regulation & 0.9 & 0.3 \\
\hline Total & 171.2 & 350 \\
\hline
\end{tabular}

The program "Digital Economy of the Russian Federation" poses not so many economic tasks related to the development of the digital industry as a whole, as well as new ways of producing and introducing domestic technologies to global markets. The program lacks some indicators: there is neither a share of electronic commerce in turnover, nor a share of hightech jobs in the overall employment structure, nor indicators of high-tech exports, nor many other indicators directly related to the digitalization of the economy. 
The program does not include incentives for large companies (especially natural monopolies), as well as medium and small businesses to more actively introduce digital innovations and increase investments in research and development. Basically, the program is aimed at creating basic "services" for the development of the economy: regulation, public services, IT infrastructure, which is also of great importance.

The TABLE III (data taken from [18]) shows that until 2020 , it is planned to spend more than 521 billion rubles on the implementation of roadmaps in four areas of the Digital Economy of the Russian Federation program, of which about 171.2 billion will be allocated from the country's budget, and extrabudgetary funding will amount to about 350 billion rubles. By 2024, all data is planned to be available for use on digital platforms [19-20]. A separate concept will appear for communications networks. A master plan for developing data center infrastructure will also be developed. Thus, higher education today faces the challenge of developing educational programs that meet modern requirements of training of specialists, competitive on the labor market in a digital economy. Such competitiveness can provide competence, directed mainly at the skills of work with modern information technologies, and for IT professionals - on skills of creating modern information technologies and systems [21-22]. In this connection it is necessary to provide students with sufficient experience of practical work with modern information technologies, which can be obtained at practical and laboratory classes. And we need to start this from the school bench at computer science lessons. Indeed, only those educational projects that use modern digital technologies and innovative strategies are competitive in the labor market and socially significant for the formation of the educational and cultural environment of the modern generation.

\section{References}

[1] N.L. Sokolova, "Digital culture or culture in the digital age", Int. Journal of C. Studies, vol. 3, pp. 6-10, 2012. Retrieved from: http://www.culturalresearch.ru/files/open_issues/03_2012/IJCR_03 \%288\%29_2012.pdf

[2] G.I. Abdrakhmanova, L.M. Gokhberg, G.G. Kovaleva, Information society: the demand for nformation and communication technologies by the population of Russia. Moscow: NIU VSHE, 2013. Retrieved from: http://www.pravo.gov.ru (accessed 27.12.2013).

[3] Strategy of information society development in the Russian Federation for the years 2017-2030, Approved by the decree of the President of the Russian Federation, vol. 203, 2017. Retrieved from: http://kremlin.ru/acts/bank/41919

[4] The program "Digital economy of the Russian Federation", Approved by the Decree of the Government of the Russian Federation, vol. 16, no. 32, July 2017, Retrieved from: http://static.government.ru/media/ files/9gFM4FHj4PsB79I5v7yLVuPgu4bvR7M0 pdf

[5] Report "Digital Economy: Global Trends and Practice of Russian Business". Retrieved from: https://imi.hsi.ru/pr2017 (accessed 08.01.2018).
[6] Digital Russia: a new reality. July 2017, Retrieved from: https://www.mckinsey.com/ /media/McKinsey/Locations/E (accessed 08.01.2018).

[7] Educational portal of the Voronezh region. Retrieved from: http://xn80aabfbrlk8bdbdxj.xn--p1ai/page_id=9382

[8] Russian newspaper 2019. Retrieved from: https://ntinews.ru/news/tsifrovaya-ekonomika/v-rossiyskikh-vuzakhstartuet-razrabotka-modeley-tsifrovogo-universiteta.html

[9] I.P. Bogomolova, E.I. Krivenko, E.S. Stryapchikh, T.V. Shevaldova, "Innovative development as an effective organization strategy", Proc. of VSUET, vol. 80, no. 1(75), pp. 398-412, 2018.

[10] O. Gor'kovaya, "New era. Why should a school participate in the development of the digital economy". Retrieved from: https://www.forbes.ru/karera-i-svoy-biznes/367693-novaya-era-zachemshkole-uchastvovat-v-razvitii-cifrovoy-ekonomiki (accessed 2019)

[11] C. Cagnin, A. Havas, O. Saritas, "Future-oriented technology analysis: Its potential to address disruptive transformations", Technol.l Forecast. and Soc. Change, vol. 80, pp. 379-385, 2018.

[12] Top 10 most expensive companies in the world in 2017. Retrieved from: http://moneymakerfactory.ru/spravochnik/ samyie dorogie-kompaniimira (accessed 08.01.2018).

[13] E.N. Kovaleva, D.S. Saiko, D.V. Arapov, "About one approach to the classification of cognitive processes of self-education", pp. 71-72, 2018 [XV All-Russ. Sci.-pract. Conf. Problems of practical training of students. Promotion of employment of graduates: problems and solutions, 2018]

[14] Yu-Hui Wanga Chia-Ching Hsiehb, "Explore technology innovation and intelligence for IoT (Internet of Things) based eyewear technology", pp. 281-290, 2018. Retrieved from: https://www.sciencedirect.com/ science/article (accessed 08.01.2018)

[15] E.N. Kovaleva, "Issues of professional growth of mathematics teacher in the conditions of formation of the digital economy", Modern probl. of Human. and soc. Sci., vol. 2, no. 24, pp. 40-44, 2019.

[16] S.G. Tikhomirov, I.A. Avtsinov, Y.A. Turovsky, A.S. Surovtsev, A.A. Adamenko, E.N. Kovaleva, "Hardware-software complex for managing biotechnological systems using intelligent information technologies", Proc. of of Voronezh State Univer. Ser. Syst. Anal. and Inform. Technol., vol. 3, pp. 158-165, 2019.

[17] L. Grillia, M. Mazzucatob, M. Meolic, G. Scellatode, "Sowing the seeds of the future: Policies for financing tomorrow's innovations", Technol. Forecast. and Soc. Change, vol. 127, pp. 1-7, 2018.

[18] Retrieved from: http://government.ru

[19] K.V. Chekudaev, E.E. Zhukova, "Application of PEST and SNW analysis methods to determine an enterprise's development strategy", pp. 101-105, 2019 [XI Int. sci. and pract. Conf. State and Business. Ecosystem of the digital economy. North-West Institute of Management, RANEPA under the President of the Russian Federation, 2019].

[20] I.V. Platonova, E.V. Gorkovenko, K.V. Chekudaev, "The system of indicators for assessing the innovative mechanism of an enterprise", Econ. and Entrepreneurship, vol. 1, p. 360, 2013.

[21] G.N. Egorova, A.A. Derkanosova, N.I. Grebennikova, "Technological approach in the application of the arsenal of pedagogical tools", Proc. of VSUET, vol. 10, no. 5-2, pp. 65-68, 2014.

[22] G.V. Alekseev, E.V. Egoshina, M.I. Borovkov, G.N. Egorova, "The use of segment analysis to develop a development strategy for an educational institution", Proc. of VSUET, vol. 3, no. 65, pp. 224-227, 2015. 